\title{
The Possibility of Peace between Hamas and Israel
}

\author{
Faisal WARIKAT ${ }^{1 \odot}$
}

\begin{abstract}
This paper investigates the possibility of establishing peace between Hamas and Israel, based on the politicisation model of armed groups that leads eventually to change the violent character of armed groups. The main question is: Can Israel and Hamas have a long-lasting peace to end the conflict in the Gaza Strip? The main pillars of politicisation are the willingness of warring parties to conclude peace, the existence of a 'hurting stalemate', the narrowness of objectives and the ability to guarantee public support. The primary conclusion of this paper is that comprehensive peace is difficult to achieve, but a unique long-term truce 'Hudna' is attainable.
\end{abstract}

Keywords: Hamas, politicisation, terrorism, Gaza, resistance group, armed group

\section{Introduction}

Revolutions rarely compromise; compromises are made only to further the strategic design. Negotiation, then, is undertaken for the dual purpose of gaining time to buttress a position (military, political, social, economic) and to wear down, frustrate and harass the opponent. Few, if any, necessary concessions are expected from the revolutionary side, whose aim is only to create conditions that will preserve the unity of the strategic line and guarantee the development of a 'victorious situation'?

Tensions between Israel and Hamas started even before the establishment of Hamas in 1987, Sheikh Ahmad Yassin, one of the principal founders of the group, was imprisoned in 1983 for stockpiling small arms illegally; he was sentenced to 13 years; in 1985 was released as a part of the Popular Front - General Command agreement with Israel. Throughout its existence, Hamas suffered from loss of its leaders through leadership targeting, large-scale military operations and various economic sanctions; nevertheless, that did not compromise its survival.

Hamas started as a resistance movement in 1987 by taking part in the First Intifada and the Second Intifada; in 2006, it held a landslide victory in the parliamentary elections against its archrival Fatah. That victory entitled Hamas to form the first democratic government

PhD student, researcher, University of Public Service; e-mail: faisal.warikat@uni-nke.hu

Samuel B Griffith (trans.), Mao Tse-Tung on Guerilla Warfare (Washington: Department of the Navy, 1989). 
within the Palestinian Authority (PA). However, Israel and the U.S. administration rejected those results; interestingly, pundits believe that victory was a result of the Palestinians dissatisfaction by the performance of the PLO. According to Hroub, it was not only the strength of Hamas but also the weakness of Fatah that attributed to that victory. ${ }^{3}$

The purpose of this article is to discuss the possibility of concluding a peace deal between Hamas and Israel. This can lead to ease the suffering of Gazans who are in a dire situation with about two million living in $362 \mathrm{~km}^{2}$; however, the article claims that a long-standing comprehensive political peace agreement between Hamas and Israel is not possible in the current time, with the preponderance of Israeli power and the imbalance that occurred after the deal of the century and the appalling Palestinian division among the different Palestinian factions. Israel and Hamas, at best, can conclude a security and humanitarian deal that pauses the conflict for a limited period.

The proposed definition of politicisation in this article is 'the use of a political process to incur a change of the role nature of armed groups into becoming a political entity that has no connection with the use of violence as a mean to achieve its objectives'. This process is usually accompanied by economic and political gestures from the involved states.

The main theoretical conditions for politicisation are established based on academic research obtained by studying 648 terrorist organisations that operated between 1968 and 2006. Jones and Libicki found that 43 per cent of these groups ended their terrorist activities due to the political process. ${ }^{4}$

There are several ranges of variables that affect a group's craving to turn toward a successful politicisation process. Firstly, the group's organisational structure, networked organisations are less likely to negotiate than hierarchical groups. ${ }^{5}$ Secondly, public support and its importance to the group. Thirdly, the existence of a hurtful stalemate between the group and its antagonists. ${ }^{6}$

Another condition to consider is the breadth of objectives ${ }^{7}$ that contributes to the success of negotiations between states and armed groups; groups with narrow policy goals mean narrow policy changes. Minor territorial changes with narrow objectives make it easier for governments to concede to armed groups' demands. Goals can range from narrow goals (such as forcing governments to change a specific policy) to broader ones (such as the goal of overthrowing multiple regimes), examples include the United Self-Defense Forces of Colombia, and to some extent loyalist paramilitary groups in Northern Ireland, like the

3 Khaled Hroub, Hamas: A Beginner's Guide (London: Pluto Press, 2006).

4 Seth G Jones and Martin C Libicki, How Terrorist Groups End: Lessons for Countering al Qa'ida (Santa Monica, CA: RAND Corporation, 2008).

5 Audrey Kurth Cronin, How Terrorism Ends: Understanding the Decline and Demise of Terrorist Campaigns (Princeton: Princeton University Press, 2009).

6 William Zartman, 'The Timing of Peace Initiatives: Hurting Stalemates and Ripe Moments', The Global Review of Ethnopolitics 1, no 1 (2001), 8-18.

7 In this paper, the breadth of objectives might not coincide with the same suggested by other experts; the broader here means the ones that are difficult for the state to accept as they jeopardise its survival, while the narrow objectives are those that governments can discuss and approve, for example, giving more political rights to deprived ethnicities. 
Ulster Volunteer Force. At the end, pursuit of peaceful solutions with groups that do not adapt their objectives to narrow ones is a waste of time. ${ }^{8}$

At the same time, negotiation should not deprive the group's sense of presumed victory; groups typically end their activities when their announced objectives have been achieved, as was the case with The Irgun Group and its offshoot Stern gang in Israel after 1948. Governments throughout history claim that terrorism is ineffective as an instrument of political change. Nevertheless, previous examples provide convincing evidence to the contrary. ${ }^{9}$

As far as states are concerned, the primary variable is their willingness to reach a peace settlement and negotiate with 'terrorist organisations'. Some countries claim that they cannot negotiate with those whose 'hands are stained with innocent blood'; however, historically, most states have negotiated directly or indirectly with terrorist groups, for example, Colombia successfully negotiated with the FARC, and the U.K. with the IRA.

Indirect negotiations between Hamas and Israel are directed mainly by the Egyptian Intelligence and limited United Nations (UN) supervision to achieve unstable peace between both parties. Deals never went to the level of a peace agreement; it is not a strategic agreement with political ends like the previous ones announced by Sheikh Yassin, which talked about an Israeli withdrawal from the occupied territories after 4 June 1967, return of refugees, Jerusalem status, security and borders.

The suggested deal is more to be named by a long-term truce or 'Hudna'. Some people prefer to call it 'Tahdiaa'. ${ }^{10}$ This agreement entails a return of missed in action Israeli soldiers' bodies, lifting the siege over Gaza, allow inhabitants of Gaza to travel through Israel to the West Bank and beyond, plans for a Gaza seaport with agreed security measures. For all that, Hamas needs to exercise its authority in the sector over itself and over other Palestinian factions.

\section{Factors affecting Hamas's ability to conclude a peace agreement with Israel}

The main variables that hold Hamas and Israel back from concluding long-lasting settlement are public support, breadth of objectives, ideological stance, division between Hamas and Fatah.

8 Andrew H Kydd and Barbara F Walter, 'The Strategies of Terrorism', International Security 31, no 1(2006), 49-80.

$9 \quad$ Bruce Hoffman, Inside Terrorism (Columbia University Press, 2006), 61.

10 'Tahdiaa' means the pacification of violent activities between the warring parties, though from a language perspective it hints that Tahdiaa is concerned about a limited and short interval of time. Some think that Hudna is a religious term, but that is not true, as Hudnas were signed between some Arab states like Jordan and Israel after the conclusion of the 1948 war in Rhodes. Tahdiaa means cessation of military activities for a particular limited time; it implies a short time interval. It does not imply hostilities. In English, it is more to be named ceasefire understandings. 


\section{Public support}

A leadership with public support is essential condition for concluding peace agreements, similar to what happened on the Israeli side, when Prime Minister Ariel Sharon dismantled Israeli settlements from Gaza in 2005 and when Menachem Begin withdrew from Sinai after the success of Camp David in 1978. This proves the thesis that hard decisions need leaders with aggressive attitudes, ones who have bloodstains on their hands. Hamas is sensitive to the public opinion inside Gaza and the West Bank; without having the proper public support, peace is meaningless as the main concern for Hamas is its survival, which counts on its ability to mobilise and recruit to replenish fallen fighters and be ready for future rounds of battles.

A survey about the support of peace between Hamas and Israel was distributed in the West Bank, and results came as follows.

Table 1: Public support for peace process

\begin{tabular}{|l|c|}
\hline \multicolumn{1}{|c|}{ What } & Percentage \\
\hline Support for a long-term truce between Hamas and Israel ('Hudna’) & 40 per cent \\
\hline Peace between Hamas and Israel will impact the popularity of Hamas negatively & 70 per cent \\
\hline
\end{tabular}

Source: Compiled by the author.

40 per cent of the respondents answered that they welcome a Hudna between Hamas and Israel, while 70 per cent of the same group answered that Hamas's popularity decreases in the aftermath of such agreement. This result shows that peace with Israel has to be in line with Palestinian's expectations; otherwise, it can be disastrous to Hamas.

Another survey done by the Palestinian Center for Policy and Survey Research (PCPSR) in 2019 reveals that 52 per cent (down to 44 per cent in the Gaza Strip) believes that the chances for a Hamas-Israel agreement on a long term Hudna or cessation of violence are slim, while 36 per cent think that chances are medium, only 10 per cent believe that chances are high. ${ }^{11}$

In 2006, Hamas won the Palestinian Legislative Council (PLC) elections, which gave a clear indication of its popularity. The movement's election platform, along with four independent candidates supported by Hamas, reaped almost 60 per cent of the votes, with a result of 78 per cent of eligible voters, but that is not reflective to Hamas's weight within the Palestinian community; that victory was primarily attributed to the failure of Fatah at that time in many administrative issues. Khaled Hroub believes that Hamas's bedrock popularity with the Palestinian constituency ranges from 30 to 40 per cent. ${ }^{12}$

The Palestinian people's support for peace is also evident in two separate polls held by two Palestinian centres under the supervision of David Pollock. The results for the questions to a formal ceasefire with Israel garners more support than opposition: 73 to 25 per cent in one poll; 51 to 45 per cent in the other. On the question of complete peace with Israel, both polls show more popular support than opposition. One poll shows Gazans

PCR, 'Public Opinion Poll', s. a.

Hroub, Hamas, 80. 
say yes by a margin of 53 to 45 per cent; the other poll yields a slightly narrower margin, 48 to 44 per cent ${ }^{13}$ in 2018. This poll testifies that people in Gaza need peace and look for it.

\section{Ideological constraints}

There are some obstacles embedded within Hamas’s 1988 Charter; in 2017 Hamas published its new political charter, which modified its previous charter. The main amendments in this political program are: 'Hamas affirms its position that its conflict is with the Zionist project in Palestine not with the Jews. Hamas movement does not wage a struggle against the Jews because of their religion but instigates a struggle against the Zionists who occupy Palestine. Secondly, the new charter abandons past references claiming Hamas is part of a pan-national Muslim Brotherhood (MB), to which it was closely linked when formed'; this new position helped Hamas in improving its contacts with the Egyptian regime.

\section{Breadth of objectives}

In this respect, Hamas cannot claim the liberation of the whole of historic Palestine as a realistic demand for peace with Israel. Hamas changed its tone to cope with international demands. In a 2008 interview, the chief of Hamas Politburo Khaled Mishal offered that a peaceful resolution could be achieved with the establishment of a Palestinian state with full sovereignty based on the 1967 borders, including East Jerusalem, without Israeli settlements. ${ }^{14}$ This is not a new offer and is along the lines offered by Sheikh Ahmad Yassin and Abed al-Aziz al-Rantissi, and others as far back as $1996 .{ }^{15}$ Currently, the objectives of Hamas are getting narrower to be humanitarian-oriented aimed at improving the living standards of Gazans and a return of prisoners and detainees in the Israeli prisons.

\section{The existence of the Mutually Hurting Stalemate (MHS)}

William Zartman ${ }^{16}$ claims that 'Parties resolve their conflicts only when they are ready to do so-when alternative, usually unilateral means of achieving satisfactory results are blocked, and the parties feel that they are in an uncomfortable and costly predicament. At that ripe moment, they grab on to proposals that most of the time has been in the air for a long time and that only now appear attractive'. ${ }^{17}$

\footnotetext{
13 David Pollock, ‘A Nation Divided: Palestinian Views on War and Peace with Israel', The Washington Institute, 22 June 2020.

14 Al-Jazeera English, 'Talk to Al Jazeera - Khaled Meshaal: Struggle is against Israel, not Jews', 07 May 2017.

15 Zaki Chehab, Inside Hamas: The Untold Story of Militants, Martyrs and Spies (London - New York: Tauris, 2007).

16 Zartman is a scientist and writer of conflict management.

17 Zartman, 'The timing of peace initiatives'.
} 
The ripeness of a moment is one of the absolute essences of diplomacy, wrote John Campbell, 'You have to do the right thing at the right time', without indicating definitive causes. ${ }^{18}$ He also said that: 'Stalemate is the most propitious condition for settlement.' Conversely, practitioners usually hear that specific mediation initiatives are not advisable because the conflict is not yet ripe.

The concept of a ripe moment focuses on the parties' perception of a 'Mutually Hurting Stalemate' (MHS), optimally linked with an impending past or recently avoided catastrophe. ${ }^{19}$ MHS is based on the perception that when the involved parties find themselves locked in a conflict or war from which they cannot escalate to victory, and this deadlock hurts both of them, they ask for an alternative policy or way out. The crisis provides a deadline or a lesson indicating that pain can be sharply increased if nothing is done about it now.

Israel failed in subjugating Hamas by the use of different methods, ranging from targeting of senior leaderships to the wage of military operations against Hamas. ${ }^{20}$

Hamas proved its ability several times to hurt Israel whenever it liked; according to Israeli human rights organisation B'Tselem, Palestinian factions killed about 1,426 Israelis 'civilians and military' from 1987 to 1996, and Israelis killed 5,050 Palestinians during the same period (137 Israeli children and 998 Palestinian children, less than 18 years old). ${ }^{21}$

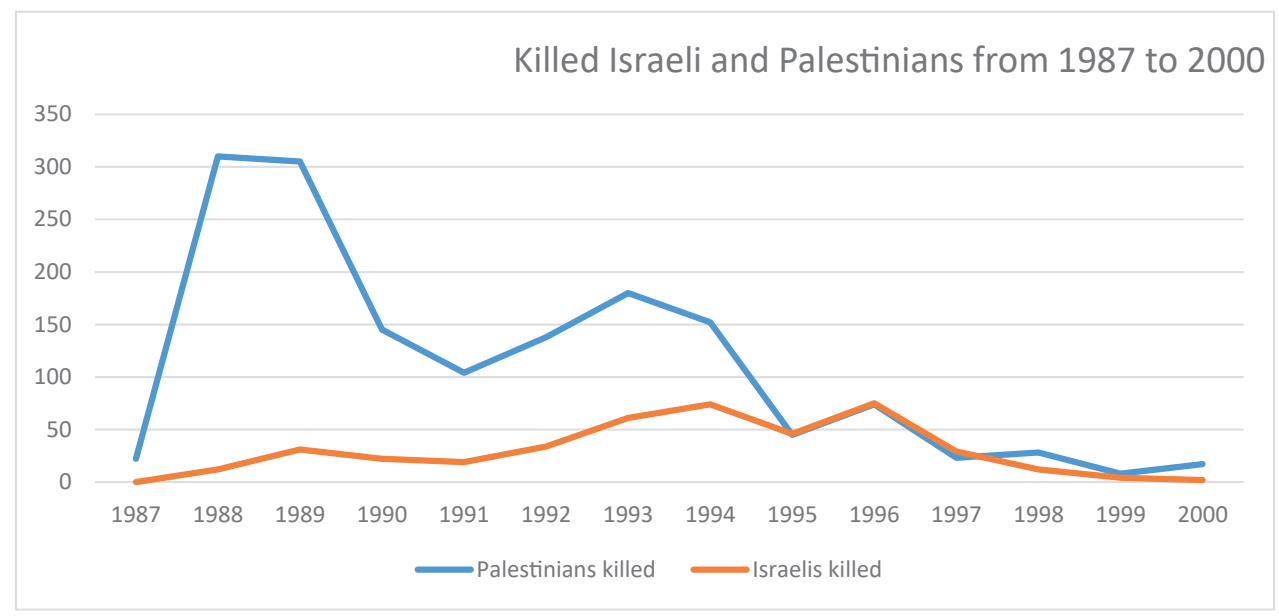

Figure 1: Comparison of fatalities among Israelis and Palestinians

Source: Data from B’Tselem.

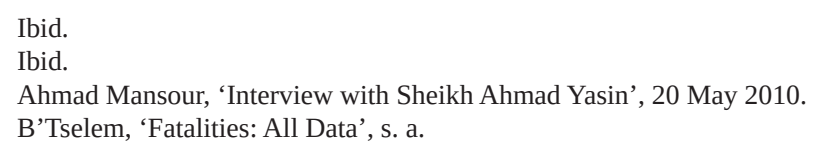




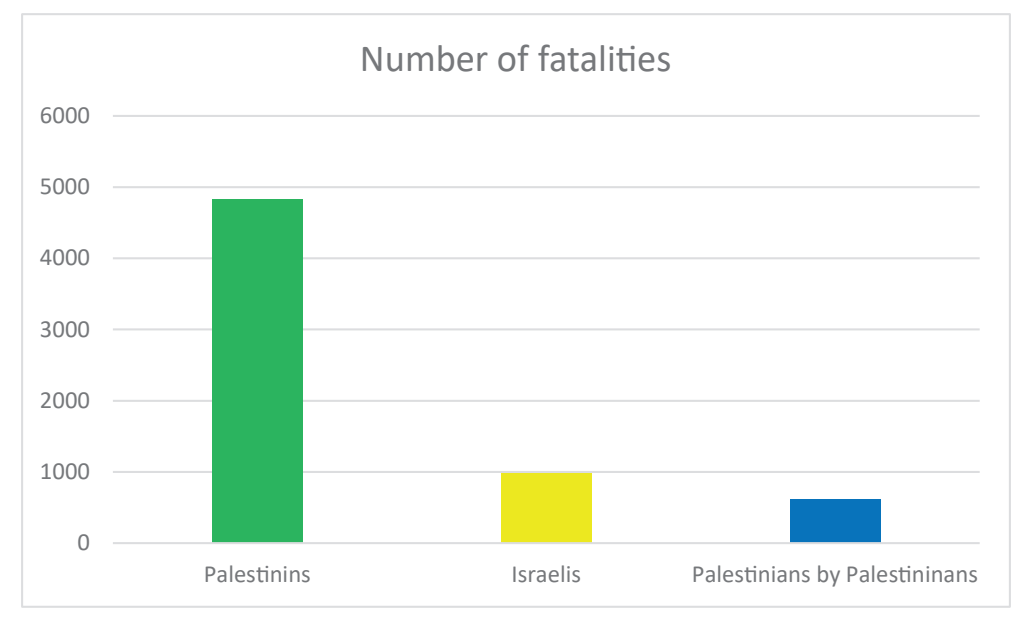

Figure 2: Number of fatalities from 2000 to 2008

Source: Data from B’Tselem.

Those statistics demonstrate that Hamas managed to inflict damages inside Israel and Israel has interest to have some kind of peace with it.

\section{Organisational structure}

The organisational structure might hinder or enhance the chances of success for peace deals, one of Hamas's advantages is the separation of outside political leadership (mainly present in Qatar and Turkey), from its military wing. Hamas's organisational structure is divided into three parts: West Bank, Gaza and outside political leadership, with seven geographical regions in the West Bank and five in Gaza. ${ }^{22}$ It has a strong leadership in Ismail Haniyah; his leadership is mainly based on democratic legitimacy as most Gazans favour him even inside the West Bank. Simultaneously, the military wings are expected to play partially against concluding a complete peace agreement with Israel.

\section{The loss of state sponsorship}

Structural reforms happen when the group loses its main contributor; an example is the FMLN in El Salvador after the collapse of the USSR. The total dependence on state

22 Jacob N Shapiro, The Terrorist's Dilemma: Managing Violent Covert Organizations (Princeton: Princeton University Press, 2013). 
sponsorship impedes peace agreements unless the sponsored state endorses the proposed agreement.

Hamas is still in good relation with Iran; its relations with Egypt were affected by the Muslim Brotherhood's weakness (MB), but currently started to improve.

Its neutral stance during the Syrian civil war caused her the loss of the Syrian support, though, when Yahiya Sinwar took over from Ismail Haniyeh in 2017 as the leader of Hamas in Gaza, he returned the relation with Hezbollah and Iran to its normalcy. However, it is believed that Iran will hinder any political solution between Hamas and Israel.

\section{Reason for survival}

The Palestinian Authority (PA) is stringent in demanding to disarm Hamas and other factions before their transformation into a political entity. Ironically, the minute Hamas stops fighting Israel, Fatah and other Palestinian groups will be portrayed as a traitor to the resistance cause.

Armed groups like Hamas and Hezbollah need a pretext of conflict to remain in life and compete with other local competitors' 'raison d'être', when they lose the resistance reason for survival, they are compared to other secular groups.

One of the primary reasons that militarised Hamas in 1987 and expedited its shift from being social services provider is that most of its supporters left to join the Palestinian Islamic Jihad (PIJ). ${ }^{23}$

Omar Shaban, ${ }^{24}$ a Palestinian expert, claims that people in Gaza are classified into three main groups about Hamas: the first group are supporters of Hamas; the second group are anti-Hamas like Fatah supporters; the last group is the not-caring ones, but mostly they sympathise with what they feel is suitable for themselves. The first group might not accept peace with Israel, but in the end, they are committed to the cause of Hamas, the second group will exploit any peace deal to stigmatise Hamas and attack its credibility; the third group will build their opinion upon the change they notice in their everyday life.

\section{The main factors affecting the Israeli side}

\section{Ideological stance}

The Zionist identity is based on the value of Jerusalem and that Palestine or 'Judea and Samaria' are the biblical land of the Israelites. The historical suffering of the Jews gave them a distinct identity that magnifies the paranoid character and suspicion of other 'Gentiles'. The ideological view about Gaza is not the same as the view towards the West Bank, Gaza is not part of the biblical land for the Zionists, and it is viewed as a reservoir of economic and humanitarian problems. In contrast to its position toward the West Bank,

Chehab, Inside Hamas.

24 Personal communication, interview held with him in 2020. 
in 2005, Ariel Sharon unilaterally dismantled Israeli settlements and withdrew from the Gaza strip. So, it will not be an issue to get the required Israeli public support for a peace deal that focuses on Gaza without connecting it to the West Bank complex situation.

\section{Willingness to make peace}

Analysts and experts often quote Henry Kissinger's assertion that 'Israel has no foreign policy, only domestic policy’. While stressed too strongly, Kissinger’s comment captures well the common understanding among political scientists and international relations specialists that domestic considerations have a significant effect on the Israeli foreign policy. ${ }^{25}$

During a lecture in Budapest, Avigdor Liberman answered about a peace deal with Hamas that it is a low-intensity conflict and Israel can live with it. ${ }^{26}$ In terms of quality, quantity and military effectiveness, Hamas's weapons and all other Palestinian weapons combined, for that matter, have never amounted to a severe threat to the State of Israel. These weapons could only inflict harm in the form of guerrilla attacks, quick and short shootouts and suicide bombings. ${ }^{27}$

A high percentage of Israelis support ceasefire talks with Hamas, according to a survey, done as part of the Israel Democracy Institute's monthly peace index, which was released amidst reports of indirect negotiations between the state of Israel and Hamas to reach an agreement that would end months of violence and struggle along the Gaza border and improve humanitarian conditions in the Palestinian enclave of Gaza. Among Israeli Jews, 57 per cent said they support holding talks with Hamas, with those numbers peaking to 70 per cent and 81 per cent, respectively, among voters on the centre and left of the political spectrum. Right-wing voters, however, were divided, with 45 per cent supporting and 47 per cent opposing negotiations with the Hamas movement, while 60 per cent of Arab Israelis said they were in favour. ${ }^{28}$

\section{The fragmentation of the opponent}

The known devil is better than unknown angels, Hamas is well known to the Israelis since its inception, and they have an excellent database about it as a result of the detention of its principal leaders and the extensive use of informants. Sources in Israel believe that Hamas turns to be a stabilising force and tries to rein in other groups like the Palestinian Islamic Jihad (PIJ) who tries to derail stabilisation efforts in the beleaguered enclave.

25 Avi Shlaim, 'Israeli Politics and Middle East Peacemaking', Journal of Palestine Studies 24, no 4 (1995), 20-31.

26 As reported by Rozsa Erisbel (a specialist in WMD proliferation and the Mena region), who attended that lecture.

27 Hroub, Hamas.

28 Alexander Fulbright, 'The majority of Israelis back truce talks with Hamas - poll', The Times of Israel, 05 September 2018. 


\section{The effect of the deal of the century}

The Trump Peace Plan (also called 'the deal of the century') was rejected by 94 per cent of a Palestinian sample, while more than 80 per cent say that it returns the conflict to its existential roots. ${ }^{29}$ The main elements of Trump's deal are that the united, undivided Jerusalem is the capital of Israel, connecting Gaza with the West Bank, which brings economic growth to the Palestinians, disarming Palestinian groups like Hamas. The failure of the deal brought the logic that any deal without Palestinian consent is a waste of time.

\section{Conclusions}

If Hamas has thrown the gauntlet to Israel, Israel should pick up the gauntlet and explore every possibility. ${ }^{30}$

Blair, who was the envoy of the Middle East quartet - composed of the U.S., EU, UN and Russia said that the international community should have tried to 'pull Hamas into a dialogue'. He added that he and other world leaders were wrong to yield to Israeli pressure to impose an immediate boycott of Hamas after the Islamic faction won Palestinian elections in 2006. ${ }^{31}$

According to the social constructivist line of thought, both Hamas and Israel have fundamental issues to their rapprochement; Israel insists on its Jewish identity, making it unlikely to compromise on Jerusalem. Hamas is also having hindrances like its 1988 charter, though some experts believe that it is of little importance to it, ${ }^{32}$ especially after the publication of its political document in 2017. The internalisation of Hamas forces it to change its norms to adapt to the international realm set of norms that prohibits violence and call for peaceful means. Hamas's nature and ideology cannot compromise a call to eternal peace with Israel, this ideological standpoint constrains their manoeuvrability, which leads to the conclusion that Hamas and Israel are unlikely to come to a comprehensive strategic peace agreement that discusses vital issues of the Israeli-Palestinian conflict that are borders, refugees and Jerusalem; the other element that will not allow such an agreement is the expected opposition from Iran and even from Fatah.

Currently, the only option that is available for Israel and Hamas is a deal of peace that is restricted to security and humanitarian aspects entailing the release of prisoners, lifting the economic siege over Gaza, lifting movement restrictions over Gazans, more economic growth to the citizens of Gaza, the return of the Israeli soldiers to Israel, control of the border with Israel. In a nutshell, security and humanitarian truce are in the interest of both sides, it is not in the interest of Israel to have chaotic Gaza in its backyard, and Hamas likes to respond to the aspirations of the youth of Gaza to have a better future.

29 PSR, 'Public Opinion Poll (75)', s. a.

30 Gershon Baskin, 'Encountering Peace: Israeli-Hamas negotiations now!', The Jerusalem Post, 11 April 2018.

31 Donald Macintyre, 'Tony Blair: 'We were wrong to boycott Hamas after its election win',' The Guardian, 14 October 2017.

32 Khalil Shikaki, 'Peace Now or Hamas Later', Foreign Affairs 77, no 4 (1998), 29-43. 
Israel does not mind of a role of Hamas inside the Gaza strip but to restrict the dialogue inside Gaza or a prospected state in Gaza, that move could precipitate international support to the Strip; however, Hamas is not in power of limiting its authority to Gaza. ${ }^{33}$

\section{References}

Al-Jazeera English, 'Gaza, Hamas and the New Middle East', 09 December 2020. Online: www. youtube.com/watch?v=od0KzQN4TpQ

Al-Jazeera English, 'Talk to Al Jazeera - Khaled Meshaal: Struggle is against Israel, not Jews', 07 May 2017. Online: www.youtube.com/watch?v=gDf_DvTPQgQ

Baskin, Gershon, ‘Encountering Peace: Israeli-Hamas negotiations now!’ The Jerusalem Post, 11 April 2018. Online: www.jpost.com/opinion/encountering-peace-israeli-hamasnegotiations-now-549542

Boxerman, Aaron, 'Hamas head: we refused 15 billion in aid conditioned on disarming'. The Times of Israel, 27 July 2020. Online: www.timesofisrael.com/hamas-head-we-refused-15billion-in-aid-conditioned-on-disarming/

B’Tselem, 'Fatalities: All Data’, s. a. Online: https://statistics.btselem.org/en/all-fatalities/bydate-of-incident?section $=$ overall\&tab= overview

Chehab, Zaki, Inside Hamas: The Untold Story of Militants, Martyrs and Spies. London - New York: Tauris, 2007.

Cronin, Audrey Kurth, How Terrorism Ends: Understanding the Decline and Demise of Terrorist Campaigns. Princeton: Princeton University Press, 2009. Online: https://doi. org/10.1515/9781400831142

Davis, Richard, The making of an insurgent group: A case study of Hamas, vox populi and violent resistance. $\mathrm{PhD}$ thesis, the London School of Economics and Political Science (LSE), 2014. Online: http://etheses.lse.ac.uk/951/

Fulbright, Alexander, 'The majority of Israelis back truce talks with Hamas - poll'. The Times of Israel, 05 September 2018. Online: www.timesofisrael.com/majority-of-israelis-backtruce-talks-with-hamas-poll/

Griffith, Samuel B (trans.), Mao Tse-Tung on Guerilla Warfare. Washington: Department of the Navy, 1989.

Hoffman, Bruce, Inside Terrorism. Columbia University Press, 2006.

Hroub, Khaled, Hamas: A Beginner's Guide. London: Pluto Press, 2006.

Jones, Seth G and Martin C Libicki, How Terrorist Groups End: Lessons for Countering al Qa’ida. Santa Monica, CA: RAND Corporation, 2008. Online: www.rand.org/pubs/ monographs/MG741-1.html

Kydd, Andrew H and Barbara F Walter, 'The Strategies of Terrorism'. International Security 31, 1 (2006), 49-80. Online: https://doi.org/10.1162/isec.2006.31.1.49

33 Aaron Boxerman, 'Hamas head: we refused 15 billion in aid conditioned on disarming', The Times of Israel, 27 July 2020. 
Macintyre, Donald, 'Tony Blair: 'We were wrong to boycott Hamas after its election win”. The Guardian, 14 October 2017. Online: www.theguardian.com/world/2017/oct/14/tony-blairhamas-gaza-boycott-wrong

Mansour, Ahmad, ‘شاهد على العصر', 10 May 2009. Online: www.youtube.com/ watch?v=rxeFg9jm8zk\&t=26s

PCR, ‘Public Opinion Poll', s. a. Online: http://pcpsr.org/en/node/788

PSR, ‘Public Opinion Poll (75)’, s. a. Online: http://pcpsr.org/en/node/797

Pollock, David, 'A Nation Divided: Palestinian Views on War and Peace with Israel'. The Washington Institute, 22 June 2020. Online: www.washingtoninstitute.org/policy-analysis/ nation-divided-palestinian-views-war-and-peace-israel

Shapiro, Jacob N, The Terrorist's Dilemma: Managing Violent Covert Organizations. Princeton: Princeton University Press, 2013. Online: https://doi.org/10.23943/ princeton/9780691157214.001.0001

Shikaki, Khalil, 'Peace Now or Hamas Later’. Foreign Affairs, 77, no 4 (1998), 29-43. Online: https://doi.org/10.2307/20048963

Shlaim, Avi, ‘Israeli Politics and Middle East Peacemaking'. Journal of Palestine Studies 24, no 4 (1995), 20-31. Online: https://doi.org/10.1525/jps.1995.24.4.00p00037

Zartman, William, 'The Timing of Peace Initiatives: Hurting Stalemates and Ripe Moments'. The Global Review of Ethnopolitics 1, no 1 (2001), 8-18. Online: https://peacemaker. un.org/sites/peacemaker.un.org/files/TimingofPeaceInitiatives_Zartman2001.pdf; Online: https://doi.org/10.1080/14718800108405087 